\title{
EVALUATION OF MARSHALL PROPERTY OF SHORT TERM AGING OF BITUMINOUS CONCRETE MIX
}

\author{
Sreevatsa.$S^{1}$, Srikrishna $H_{D^{2}}$, Chandrahasa $H R^{3}$ \\ ${ }^{1}$ Assistant Professor, Atria Institute of technology, Hebbal, Bangalore-560024, India. \\ ${ }^{2}$ Assistant Professor, Atria Institute of technology, Hebbal, Bangalore-560024, India. \\ ${ }^{3}$ Assistant Professor, Atria Institute of technology, Hebbal, Bangalore-560024, India.
}

\begin{abstract}
Aging of bituminous pavements typically occurs through oxidation of the bitumen and evaporation of the lighter compounds from the binder. The main objective of this study is to evaluate influence of aging on performance of bituminous concrete mix. Bituminous concrete mix were prepared as per Marshall Method of mix design, and subjected to short term aging (STA) procedure which involved in heating the loose mix in oven for aging period of 1 to 5 hours with an interval of 1 hour at a temperature of $135^{\circ} \mathrm{C}$.
\end{abstract}

Keywords: Marshall Properties, Short-term ageing, Control mixture, Material characterization.

\section{INTRODUCTION}

\subsection{Short Term Aging}

India has a road network of about 4.6 million $\mathrm{Km}$ with majority of roads are flexible pavement. The top surfaces of flexible pavement are constructed mainly with the use of naturally available aggregates and bitumen binder, where aggregates are dried and mixed with hot bitumen to produce the hot mix asphalt. The properties of bituminous mix begin to change from the time of mixing, transporting from plant and laying due to aging, which are recognized as one of the major problems faced by bituminous mix during its service life, Aging causes the bituminous mix to stiffen and become brittle which leads to a higher potential for fatigue and thermal cracking. It was found that four hours of oven aging at $135^{\circ} \mathrm{C}$ appears representative of the short-term aging in the field during mixing and placement.

\subsection{Material Characterization}

The materials used in this work are bitumen binder, aggregate and filler. The properties of materials were tested as per the relevant test procedures and the results were compared with MORT\&H specified limits. The bitumen binder used in this work is VG-30. It was obtained from Mangalore Refineries and Petrochemicals Ltd. (MRPL). The bitumen properties are shown in Table 1. The aggregate used in this work was obtained from a local quarry near Mydala, Tumkur District. This aggregate is widely used in Tumkur city for bituminous mixes. The coarse and fine aggregates used in this work were sieved, and recombined in proper proportions to meet the wearing course gradation as per MORT\&H specifications. The physical properties and selected gradation curve for the aggregates are presented in Table 2 and Fig 1 respectively.

Table 1: Properties of VG-30 bitumen

\begin{tabular}{|l|l|l|l|l|}
\hline Sl no & Properties Code & Results & $\begin{array}{l}\text { Requirements as } \\
\text { per MORT\&H }\end{array}$ \\
\hline 1 & $\begin{array}{l}\text { Penetration at } 25^{\circ} \mathrm{C} \\
(\mathrm{mm})\end{array}$ & IS 73:2006 & 65 & $50-70$ \\
\hline 2 & Ductility at $25^{\circ} \mathrm{C}(\mathrm{cm})$ & IS 73:2006 & 74 & Min 45 \\
\hline 3 & Softening point $\left({ }^{\circ} \mathrm{C}\right)$ & IS 73:2006 & 52 & Min $45^{\circ} \mathrm{C}$ \\
\hline 4 & $\begin{array}{l}\text { Specific gravity at } \\
25^{\circ} \mathrm{C}\end{array}$ & IS 73:2006 & 1.01 & $0.97-1.02$ \\
\hline 5 & Flash \& Fire point $\left({ }^{\circ} \mathrm{C}\right)$ & IS 73:2006 & $\begin{array}{l}285^{\circ} \mathrm{C} \\
310^{\circ} \mathrm{C}\end{array}$ & $\begin{array}{l}\text { Min } 220^{\circ} \mathrm{C} \\
\text { Min } 270^{\circ} \mathrm{C}\end{array}$ \\
\hline
\end{tabular}

Table 2: Properties of aggregates

\begin{tabular}{|l|l|l|l|l|}
\hline Sl. No & Properties & Code & Results & $\begin{array}{l}\text { MORT\&H } \\
\text { specification }\end{array}$ \\
\hline 1 & Aggregate Impact value & IS:2386 Part 4 & $21.8 \%$ & $30 \% \max$ \\
\hline 2 & Los Angeles Abrasion value & IS:2386 part 4 & $24.23 \%$ & $30 \% \max$ \\
\hline 3 & Aggregate Crushing value & IS:2386 part 4 & $22.87 \%$ & $30 \% \max$ \\
\hline & Specific gravity & & & \\
\hline
\end{tabular}




\begin{tabular}{|c|c|c|c|c|}
\hline \multirow[t]{3}{*}{4} & $20 \mathrm{~mm}$ down & \multirow[t]{3}{*}{ IS:2386 part 3} & 2.6 & $2.5-3.2$ \\
\hline & $12.5 \mathrm{~mm}$ down & & 2.54 & $2.5-3.2$ \\
\hline & Dust & & 2.52 & - \\
\hline \multirow{4}{*}{5} & Water absorption (\%) & \multirow{4}{*}{ IS:2386 part 3} & & \\
\hline & $20 \mathrm{~mm}$ down & & 0.36 & $\operatorname{Max} 2 \%$ \\
\hline & $12.5 \mathrm{~mm}$ down & & 0.54 & Max $2 \%$ \\
\hline & Dust & & 2.89 & - \\
\hline
\end{tabular}

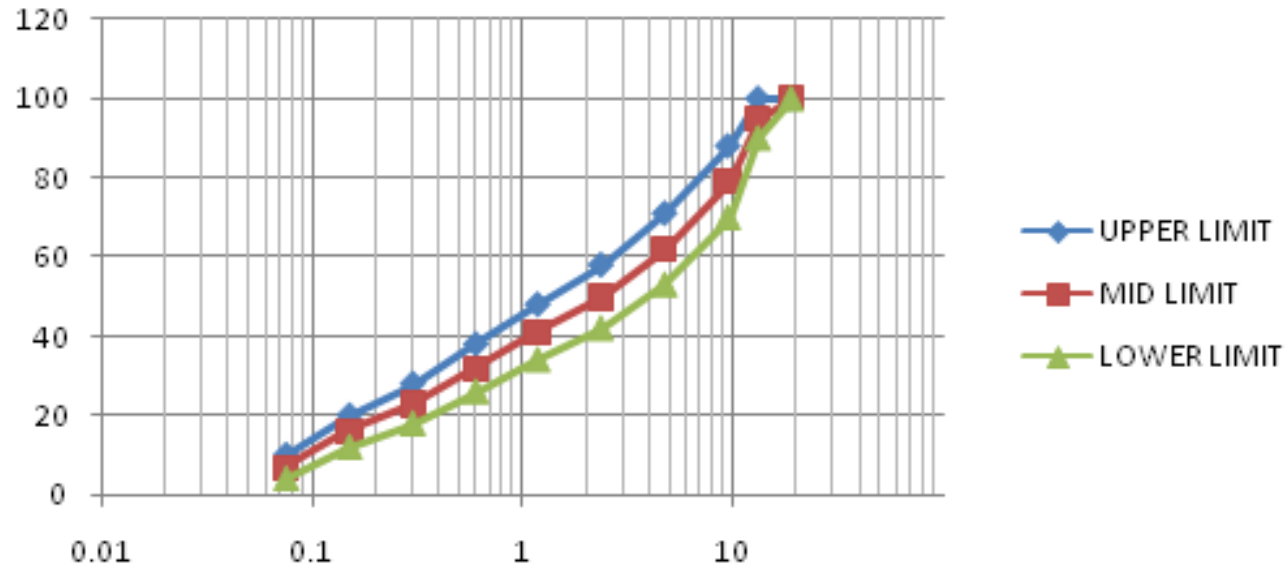

Fig 1: Gradation curve

\subsection{Preparation of Mixtures}

Two types of mixtures were prepared for the study using Marshall Method of mix design, control mixture, short term aged mixtures.

\subsection{Preparation of Control Mixture}

The efficiency of mixing procedure depends on providing homogenous mix and uniform coating of aggregate with bitumen binder. The aggregates were washed, dried to a constant weight at $110^{\circ} \mathrm{C}$, and then sieved. The graded aggregates were heated to a temperature of $160^{\circ} \mathrm{C}$ before mixing with bitumen. The bitumen binder was heated to a temperature of $160^{\circ} \mathrm{C}$ and added to the heated aggregates to obtain desired weight, and mixed thoroughly by spatula for 2 minutes until all aggregate particles were coated with bitumen binder. The mix is filled in the Marshall Mould assembly. The temperature of the mixture immediately prior to compaction was kept between $140-150^{\circ} \mathrm{C}$. Then, 75 blows were on the top applied and bottom of the specimen with a compaction hammer of $4.5 \mathrm{~kg}$ sliding weight, with a free fall of $457 \mathrm{~mm}$. The specimen in mould was left to cool at room temperature for 24 hours and then removed from mould by using sample extractor.

\subsection{Short-Term Aging}

The Marshall method of mix design was adopted to prepare the bituminous mix to simulate short term aging in the lab. The loose mix was spread to an uniform thickness in the pan and placed in an oven for 1 to 5 hours at a temperature of $135^{\circ} \mathrm{C}$ to obtain bituminous concrete mixes of different aging. The loose mix was compacted in the same way as that of control mix.

\section{EXPERIMENTAL METHODS AND RESULTS DISCUSSION}

The experimental work was started by determining the optimum binder content for all the bituminous mix using the Marshall method of mix design. Table 3 shows the experimental programming of Marshall stability, Flow and ITS values of controlled, Short term Long term aged bituminous concrete mixes.

Table 4: Summary of the properties of bituminous mix at optimum binder content

\begin{tabular}{|c|c|c|c|c|c|c|c|}
\hline \multirow[t]{2}{*}{ Sl. No } & \multirow[t]{2}{*}{ Mix type } & \multicolumn{6}{|c|}{ Properties } \\
\hline & & $\begin{array}{l}\text { Density } \\
\text { (g/cc) }\end{array}$ & $\begin{array}{l}\text { Marshall } \\
\text { Stability } \\
(\mathbf{k N})\end{array}$ & $\begin{array}{l}\text { Flow } \\
(\mathbf{m m})\end{array}$ & $\begin{array}{l}\text { ITS } \\
\text { conditioned } \\
\text { (kPa) }\end{array}$ & $\begin{array}{l}\text { ITS } \\
\text { unconditioned } \\
(\mathbf{k P a})\end{array}$ & TSR \\
\hline 1 & $\begin{array}{l}\text { Controlled } \\
\text { mix }\end{array}$ & 2.30 & 17.77 & 2.55 & 46.05 & 52.50 & 0.88 \\
\hline 2 & $\begin{array}{ll}\begin{array}{l}\text { Short } \\
\text { aging }\end{array} & \text { term }\end{array}$ & $\begin{array}{l}\text { Density } \\
\text { (g/cc) }\end{array}$ & $\begin{array}{l}\text { Marshall } \\
\text { Stability } \\
(\mathbf{k N})\end{array}$ & $\begin{array}{l}\text { Flow } \\
(\mathbf{m m})\end{array}$ & $\begin{array}{l}\text { ITS } \\
\text { conditioned } \\
\text { (kPa) }\end{array}$ & $\begin{array}{l}\text { ITS } \\
\text { unconditioned } \\
\text { (kPa) }\end{array}$ & TSR \\
\hline
\end{tabular}




\begin{tabular}{|l|l|l|l|l|l|l|l|}
\hline & 1 hours & 2.33 & 13.38 & 2.83 & 52.72 & 58.46 & 0.90 \\
\hline & 2 hours & 2.31 & 10.32 & 3.46 & 65.40 & 65.00 & 1.00 \\
\hline & 3 hours & 2.34 & 12.37 & 5.9 & 81.26 & 73.00 & 1.11 \\
\hline & 4 hours & 2.32 & 13.60 & 6.2 & 75.90 & 63.00 & 1.20 \\
\hline & 5 hours & 2.32 & 15.29 & 6.16 & 74.52 & 59.26 & 1.26 \\
\hline
\end{tabular}

\section{Effects of Aging on Marshall Stability}

Figure 3 shows Marshall stability for controlled, Short term oven aged and Long term oven aged bituminous concrete samples. Controlled sample has a strength of $18 \mathrm{kN}$. Short term oven aged for 2 hours show $10 \mathrm{kN}$ and is lowest. The field sample show nearly the same stability value and both have same strength. Beyond 2 hour of Short term aging, the stability increases till 5 hours.

However all samples show stability value greater than $9 \mathrm{kN}$ and meet MORT\&H specification. It can be concluded that the 2 hours Short term aging is equivalent to short term field aging due to mixing, transportation and compaction of bituminous concrete mix in the pavement.

From figure 2, the stability of bituminous concrete mix is found to be decreasing up to 2 hours of aging after which the value increases with the aging hour. This can be attributed to the loss of volatile components from the mix due to which the pavement becomes stiff and show increase in stability value.

\section{Marshall stability (kN)}

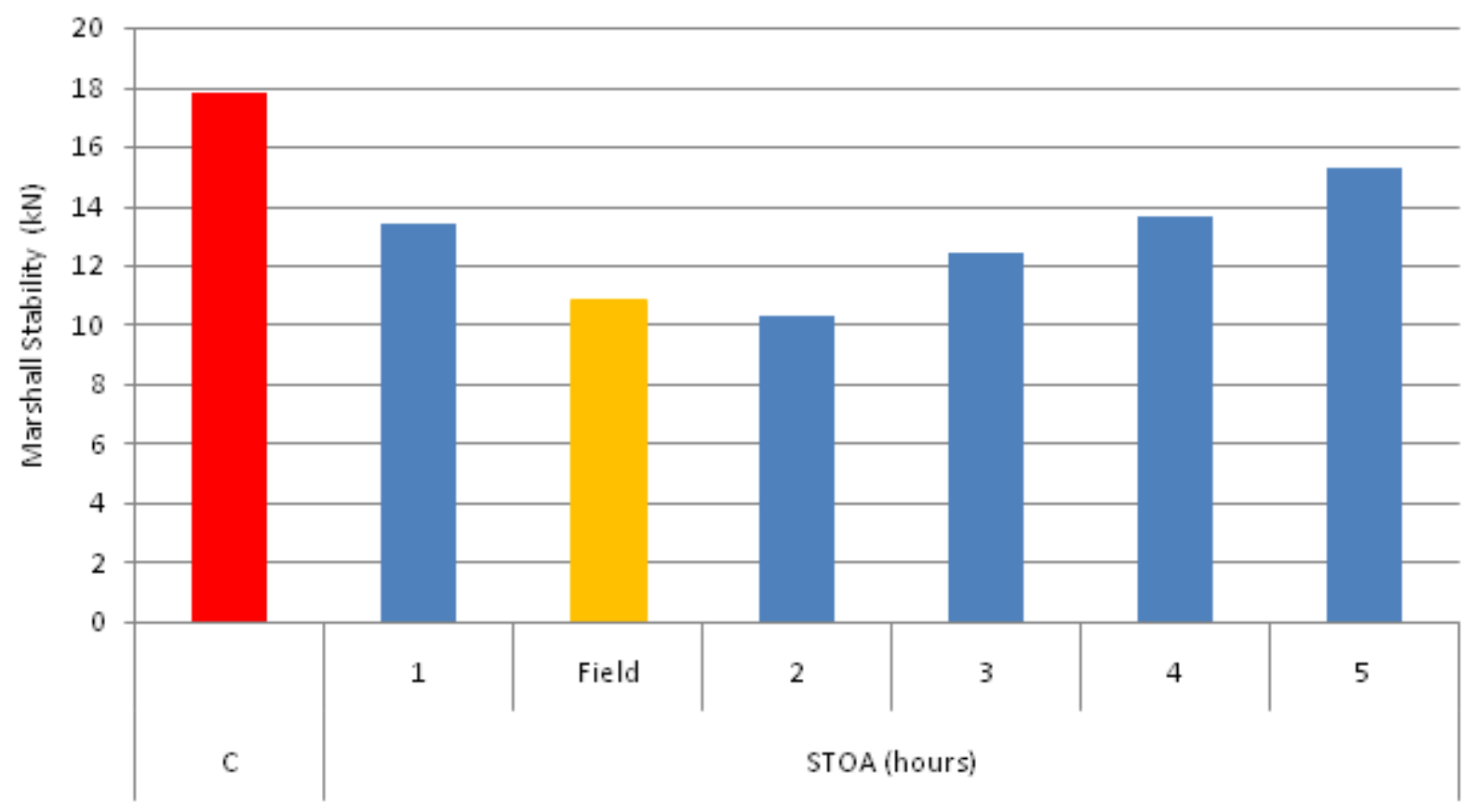

Fig 2: Marshall Stability v/s Aging

\section{CONCLUSION}

The Marshall Stability and 2 hour oven aged samples are same. Therefore, the 2 hour oven aged sample is equivalent to short term aging related to mixing, transporting, laying and compaction. The Marshall stability is high for controlled sample, decreases with aging attains minimum value at 2 hour Short term oven age and then increases.

\section{REFERENCES}

[1] AASHTO Designation R30. STANDARD PRACTICE FOR MIXTURE CONDITIONING OF HOT MIX ASPHALT.
[2] C.A. Bell, M.J. Fellin, and A. Wieder (1992) "Field Validation of Laboratory Aging Procedures for Asphalt Aggregate Mixtures" SHRP A-003A, The Institute of Transportation studies. 45-63

[3] IS 73:2006, "Paving Bitumen Specification", Indian Standards.Ministry of Road Transport and Highways Specification (2010)

[4] Mix Design Methods, Bitumen Institute Manual Series No. 2 (MS-2) Sixth Edition.

[5] S K Khanna, C E G Justo and A Veeraragavan, (2013) "Highway materials and pavement testing" Nem chand and brothers publication, revised fifth edition, 2013. 